\title{
Therapeutic Management of Trauma-related Acute Pancreatitis in a Heart Transplant Recipient
}

\author{
COSMIN BANCEU ${ }^{1}$, SIMONA GURZU², MARIUS HARPA ${ }^{1 *}$, KLARA BRINZANIUC ${ }^{1}$, MIHAELA ISPAS ${ }^{1}$, VASILE BUD ${ }^{3}$, \\ JUDIT KOVACS ${ }^{1}$, MARIAN POP ${ }^{1}$, MARIUS CIORBA ${ }^{5}$, HUSSAM AL HESSEIN ${ }^{1}$, HORATIU SUCIU ${ }^{1}$ \\ ${ }^{1}$ Institute for Cardiovascular Diseases and Transplantation of Targu- Mures, University of Medicine, Pharmacy, Science and \\ Technology of Targu Mures, 50 Gheorghe Marinescu Str., 540136, Targu Mures, Romania \\ 2University of Medicine, Pharmacy, Sciences and Technology of Targu Mures, Department of Pathology, 38 Gheorghe Marinescu \\ Str., 540139, Targu Mures, Romania \\ ${ }^{3}$ University of Medicine, Pharmacy, Sciences and Technology of Targu Mures,Department of General Surgery, Gheorghe \\ Marinescu Str., 540139, Targu Mures, Romania \\ ${ }^{4}$ University of Medicine, Pharmacy, Sciences and Technology of Targu Mures,Department of Gastroenterology, Gheorghe Marinescu \\ Str., 540139, Targu Mures, Romania
}

\begin{abstract}
Acute pancreatitis is a very mortal disease, mortality that increases even more in patients with cardiac transplantation. Medical-surgical management of acute pancreatitis in transplanted patients can make the difference between life and death. The aim of this paper was to highlight the severity of this pathology especially because the patient is immunosuppressed after cardiac transplant. A case of 36-year-old man, known with heart transplant, immunosuppressive treatment and chronic renal frailer, who arrived to Emergency Department, with severe abdominal pain and abdominal distention which started after a traumatic accident. Investigations revealed acute pancreatitis thatneeded three surgeries for acute necrotic hemorrhagic pancreatitis, acute bleeding, left subphrenic abscess and intensive care therapy. With favorable postoperative evolution, patient is discharged 60 days later He's follow up reveled no gastrointestinal or cardiac complication with an improved quality of life.
\end{abstract}

Keywords: pancreatitis, heart transplantation, immunosuppression

Pancreatitis is associated with high mortality in patients with heart transplantation(HTx) after infections and rejection complications [1]. The mortality rate is very high even if acute necrotizing pancreatitis benefits from suitable treatment [2]. $3 \%$ of patients with transplant can develop acute pancreatitis after heart transplant versus $0.1 \%$ of patients with other cardiac surgery [3], which means a high risk of death [2]. Several complications like shock, renal failure, sepsis and respiratory dysfunction can be caused by acute pancreatitis [4]. These complications are determined by the activation of the inflammatory pathway that develops a systemic inflammatory response syndrome (SIRS) [5]. Due to the immunosuppression drugs in heart transplantation, patients with acute pancreatitis have a very low survival rate [6]. Two groups of gastrointestinal complications may appear after cardiac surgery: mesenteric ischemia and pancreatitis [7]. More than 50\% of patients die during hospitalization for gastrointestinal complications after cardiac surgery [8] and about 40\% for pancreatitis if the patient develops this complication much later postcardiac surgery [7]. Hyperamylasemia after open heart surgery is a sign of acute pancreatitis and the percentage of those who develop severe pancreatitis with hemorrhagic pancreatitis or pancreatic abscess in the case of elevated amylases it's high [9]. After cardiac surgery, pancreatitis is a serious complication with significant morbidities and mortality, its incidence being even higher in patients with heart transplantation than in those with other cardiac surgeries [9-11]. The evolution of pancreatitis after HTx develops a sterile infection with pancreatic pseudo-cysts followed by systemic sepsis and multiorgan failure $[1,5,12,13]$.

The aim of this paper was to highlight the severity of this pathology especially because the patient is immunosuppressed after cardiac transplant.
Signed informed consent was obtained for publication of scientific data.

\section{Experimental part}

A 32 -year old man with end-stage heartfailure (ischemic heart disease, left venricular aneurysm with massive ventricular thrombus, $20 \%$ ejection fraction) was evaluated for cardiac transplant. He was treated with loop diuretics (Furosemide $160 \mathrm{mg} /$ day), potassium sparig diuretics (Spironolactone $50 \mathrm{mg} /$ day), beta- blockers drugs (Carvedilol $12.5 \mathrm{mg} /$ day), anticoagulant treatment with Sintrom $1 \mathrm{mg} /$ day. After 1 year on the waiting list an orthotropic transplantation was performed with bicaval technique. After 34 days, the patient was discharged from our service without special problems, with immunosuppressive treatment (Prograft 6 g/day, Cellcept 2g/day, Prednison $20 \mathrm{mg} /$ day), antiviral drug (Valcyte $450 \mathrm{mg} /$ day) antibiotic medication (Sulfamethoxazole- Trimethoprim $800 / 160 \mathrm{mg} /$ day, loop diuretics (Furosemide $80 \mathrm{mg} /$ day), potassium sparing diuretics (Spironolactone $50 \mathrm{mg} /$ day). The patientis without rejectsigns at the heartbiopsy (ISHLT 0 ). The patient is in our transplant follow up program and his evolution is without reject signs but with chronic renal failure developed two years after immunosuppression treatment was started (creatinine level $1.87 \mathrm{mg} / \mathrm{dL}$, urea $64 \mathrm{mg} / \mathrm{dL}$ ), controlled with low doses of loop diuretics Furosemide $20 \mathrm{mg} /$ day with monitoring of electrolytes, renal and hepatic function.

Three years later, he presented to the Emergency Department, with severe abdominal pain and abdominal distention which started after a traumatic accident. The laboratory investigation reveals hemoglobin ( $\mathrm{Hgb}$ ) 8.4g/ $\mathrm{dL}(11-17 \mathrm{~g} / \mathrm{dL})$, hematocrit (Htc) $23.3 \%(34-54 \%)$, creatinine $4.23 \mathrm{mg} / \mathrm{dL}(0.72-1.25 \mathrm{mg} / \mathrm{L})$, serum amylase level > $1263 \mathrm{U} / \mathrm{L}-(25-125 \mathrm{U} / \mathrm{L})$ Suspicion of acute

*email: marius_harpa@yahoo.com, Phone: +40740311396 


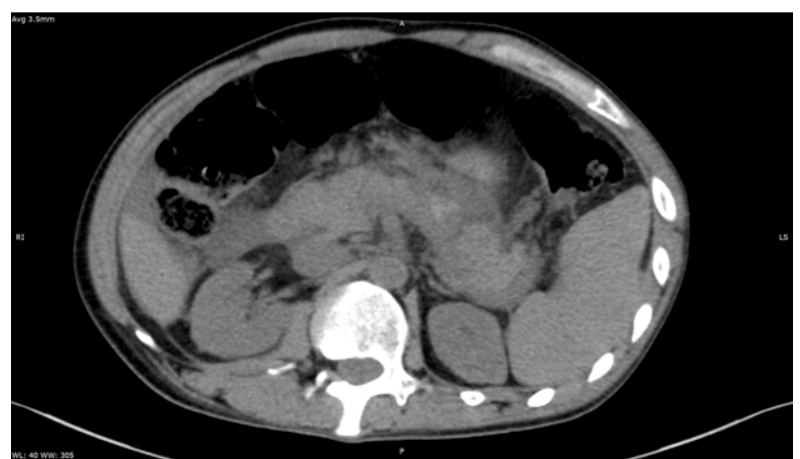

Fig. 1. Peripancreatic and mesenteric abdominal fat with edematous infiltration, fluid collections around the liver and in both paracolic gutters

pancreatitis was done. The computer tomography fig. 1) revealed peripancreatic and mesenteric abdominal fat with edematous infiltration, fluid collections around the liver and in both paracolic gutters. The CT image is suggestive of acute pancreatitis (Balthasar $\mathrm{C}$ ). He was treated with intravenous hydration ( Glucose 10\%, $\mathrm{NaCl}$ \%\%), antibiotics (Ampicillin $500 \mathrm{mg}$ every $6 \mathrm{~h}$ ), renal drugs support (Furosemide $20 \mathrm{mg}$ injectable solution tw o times per day), immunosuppressive drugs (Cellcept $5 \mathrm{mg} /$ day and Prograf $1.5 \mathrm{~g} /$ day ) and antalgic treatment with Tramadol $25 \mathrm{mg} /$ day and Metamizol sodic $1 \mathrm{~g} / 2 \mathrm{~mL} /$ day. The patient's status was not improved and after three days he develop surgical acute abdomen. The CT-exam (fig. 2) showed a mildly enlarged pancreas, still moderately edematous and a focal hyperdense lesion in the pancreatic head, presumably hemorrhagic with a large fluid collection ( 14/ $8 \mathrm{~cm})$, reasonably well delimited, with hyperdense margins, dislodging the stomach upwards (pseudocyst). The laboratory investigations revealed serum levels of amylases $1122 \mathrm{U} / \mathrm{L}$, glycemia $94 \mathrm{mg} / \mathrm{dL}$, Leukocytes 10.75

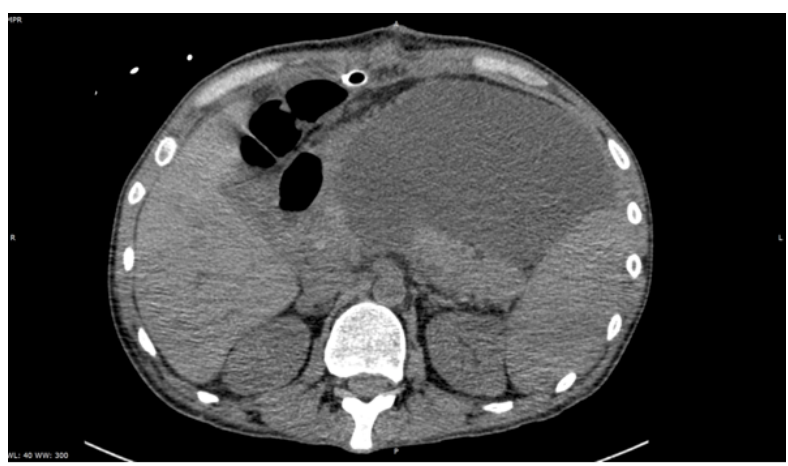

Fig. 2. Mildly enlarged pancreas, moderately edematous and a focal hiperdense lesion in the pancreatic head, presumably hemorrhagic with a large fluid collection $(\sim 14 / 8 \mathrm{~cm})$, reasonably well delimited, with hyperdense margins, dislodging the stomach upwards (pseudocyst)

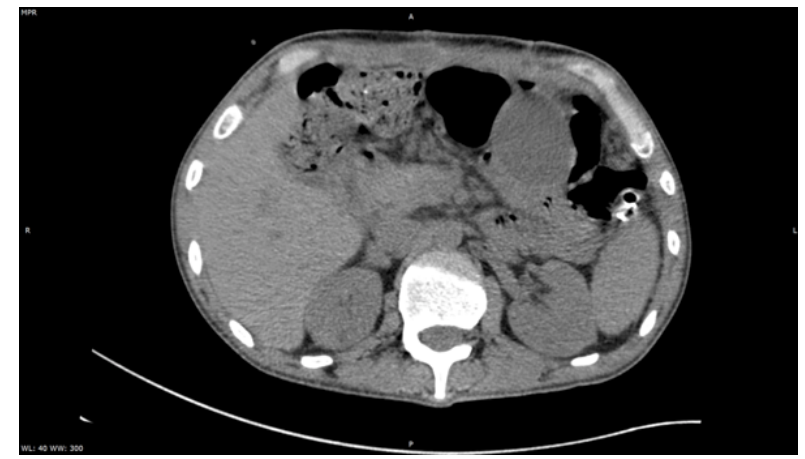

Fig. 3. $5 \mathrm{~cm}$ round lesion, bordering the abdominal wall and maintaining a rather inhomogeneous appearance, with moderate delimited margins $x 10^{3} \mu \mathrm{L}$, creatinine level $4.83 \mathrm{mg} / \mathrm{dL}$. Because of the surgical acute abdomen and laboratory investigation the patient has indication of emergent surgical treatment. Emergent surgery consisted on removing all the necrotic peri and intrapancreatic tissue and pancreatogenic exudate in order to avoid the systemic release of toxic and vasoactive substances. Also it was perform a classic cholecystectomy to avoid biliary pancreatitis. A drainage tube was installed and the patient was transferred to ICU. After two weeks of favorable evolution, patient started to have sanguineous drainage and laboratory investigations showed decreased levels of $\mathrm{Hgb}$ from $11.2 \mathrm{~g} / \mathrm{dL}$ to $8.0 \mathrm{~g} /$ $\mathrm{dL}$, hematocrit from 33 to $23.2 \%$ and increased levels of leukocytes from $11.2 \times 10^{3} \mu \mathrm{L}$ to $25.6 \times 10^{3} \mu \mathrm{L}$,. Surgical reintervention, for a diffuse pancreatic and peripancreatic hemorrhage was necessary. After long hemostasis, the patient was transferred in the ICU. Two weeks later the laboratory investigations showed increasing serum levels of amylases to $935 \mathrm{U} / \mathrm{L}$. CT-exam (fig. 3) showed a $5 \mathrm{~cm}$ round lesion, bordering the abdominal wall and maintaining a rather inhomogeneous appearance, with moderate delimited margins. In the abdominal wall, in the median axis there is a similar lesion, $1.5 \mathrm{~cm}$ in diameter which was treated by explorative laparotomy, necrosectomy, lavage and insertion of drains. During hospitalization patient received medical treatment with Targocid $400 \mathrm{mg} /$ day, Colistin 2 mil, Tienam $1 \mathrm{~g}$ and Metronidazole $500 \mathrm{mg}$ every $8 \mathrm{~h}$, Fluconazole $150 \mathrm{mg} /$ day, Biseptol every two days, immunosuppressive treatment with CellCept and Prograf, intravenous hydratation with $\mathrm{NaCl} 0.9 \%$, Aminoven $10 \%$ solution, Glucoses $5 \%$, and parenteral nutrition with Intralipid $20 \%$ infusion $250 \mathrm{~mL} /$ day. Hospitalization for 60 days was necessary for complete recovery and he was discharged with immunosuppression treatment ( Prograf $5 \mathrm{mg}$ and CellCept $500 \mathrm{mg} /$ twice per day ), loop diuretics (Furosemide $80 \mathrm{mg} /$ day), digestive enzymes (Triferment $275 \mathrm{mg} /$ twice per day), antibiotic (SulfamethoxazoleTrimethoprim 400/80 mg/ day), gastric protection with $\mathrm{H} 2$ blocker (Ranitidine $150 \mathrm{mg} /$ twice per day). He was discharged and follow up reveled no gastrointestinal or cardiac complication (fig. 4).

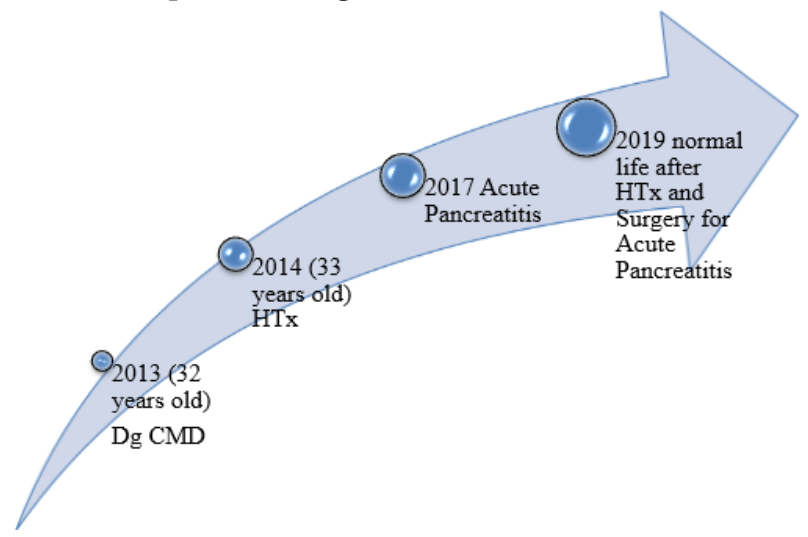

Fig. 4. Major medical events in patient's life

\section{Results and discussions}

Patients with heart, liver, intestinal kidney or bone marrow transplantation have a higher prevalence of developing acute pancreatitis compared to the others patients either by exogenous mechanism or by the druginduced pancreatitis mechanism $[10,11,14]$. The pathophysiology is altered by the immunosuppressive treatment, which increases mortality risk in transplanted versus non-transplanted patients $[6,11]$.

For example, even though pancreatitis is not among the clear side effects, it has been reported as a possible rare 
and fatal effect of long-term administration of tacrolimus [16]. Due to the absence of specific diagnostic tests, the diagnosis of acute drug-induced pancreatitis is difficult to establish,[10] but in this case we knew that the symptomatology started after an accident, so etiology was clearly post-traumatic.

One of the most serious complications after cardiac surgery is acute pancreatitis and this complication has significantmorbidities and mortality $[1,2,10]$. Severe acute pancreatitis can be associated with systemic inflammation, compensatory immunesuppression, secondary infections, vital organ dysfunction, and death [12]. The diagnosis and treatment can be delayed because transplanted patients are under immunosuppression treatment and they can develop a crypto- symptomatic acute pancreatitis, a fact that increases mortality in orthotropic heart transplant patients $[1,11,14,15]$. Even with aggressive and appropriate care, the patient can develop acute necrotizing pancreatitis witch has a high mortality rate [2].

Orthotopic cardiac transplantation and acute pancreatitis are associated with high mortality, [1-15] appearance of necrotic tissue in acute pancreatitis creating conditions for bacterial infection and development of disorders in the coagulation cascade followed by disseminated intravascular coagulation [17]. Normally, amylase/ creatinine clearence rise in acute pancreatitis but because of chronical renal failure induced by ismunosupressiv treatament, clearance in decresed and hyperamilasemia can have elevated serum levels above normal [17]. This can cause the rise of clinical manifestations of exocrine pancreatic insufficiency [18].

Even with an optimal management, acute pancreatitis is a disease with a high mortality, regardless of etiology or treatment, due to the complications that can arise [19].

\section{Conclusions}

Less commonly, pancreatitis after cardiac transplantation has a very high mortality, especially since there is no specific protocol to manage this pathology and the risk of rejection of the allograft is increased.

\section{Acknowledgements: We thank to Prof. Anca Sin for interpretation of cardiac biopsies.}

\section{References}

1.STEFANIAK T., GLOWACKI J., DYMECKI D., LACHINSK A., GRUCA Z., Pancreatitis Following Heart Transplantation: report of a case, Surg. Today., 33, no 9, 2003, p. 693.

2.KOVACS J., GURZU S., J JUNG J., SZEDERJESI J., COPOTOI S M., COPOTOI R., AZAMFIREI L., Clinico-Pathological Particularities of Shock- Related Pancreatitis, Pathol Oncol Res., 18, 2012, p. 977. 3.HERLIN J. A., PINSON C.W., WRIGHT J.K., DEBELAK J ., Acute pancreatitis after cardiac transplantation and other cardiac procedures: case-control analysis in 24,631 patients, Am Surg., 65, no. 9, 1999, p. 819.
4.BRUNICARDI F. C., ANDERSEN D.K., BILLIAR T.R., DUNN D.L., HUNTER J.G., MATTHEWS J.B., POLLOCK R. E., Schwart' s Principles of Surgery, 9, The McGraw-Hill Companies, United States of America, Andersen D.K., Billiar T.R., Dunn D.L., Hunter J.G., Matthews J.B., Pollock R. E., 2010, p. 2254

5.GURUSAMY K.S., DEBRAY T.P.A., ROMPIANESI G., Prognostic models for predicting the severity and mortality in people with acute pancreatitis. Cochrane Database of Systematic Reviews, 5, no. CD013026, 2018.

6.TABAKOVIC M., SALKIC N., BOSNJ IC J ., ALIBEGOVIC E., Case Report Acute Pancreatitis after Kidney Transplantation, Case Rep. Transplant 2012, no. 768193, 2012.

7.COHN L.H., Cardiac Surgery in the Adult, 3, The McGraw-Hill Companies, United States of America, Cohn L.H, 2008, p. 541.

8.KOUCHOUKOS N. T., BLACKSTONE E.H., DOTY D.B., HANLEY F.L., KARP R. B., Kirklin/ Barrat- Boyes Cardiac Surgery, 3, 1, Churghill Livingstone, Kouchoukos N. T., Blackstone E.H., Doty D.B., Hanley F.L., Karp R. B., 2003, p. 224.

9.HELDERMAN J.H., GORA S., Gastrointestinal Complication of Transplant Immunosuppression, J. Am. Soc. of Nephrol., 13, no. 1, 2002, p. 277.

10.FONTANA F., CAPPELLI G., Acute pancreatitis associated with everolimus after kidney transplantation: a case report, BMC Nephrol., 17, 2016, p. 163.

11.LIN T.W., TSAI M.T., ROAN J.N., LIU Y.S., TSAI H.M., LUO C.Y., Obscured hemorrhagic pancreatitis after orthotopic heart transplantation complicated with acute right heart failure and hepatic dysfunction: a case report, J Cardiothorac Surg., 11, 2016, p. 166. 12.OIVA J., MUSTONEN H., KYLANPAA M., KYHALA L., KUULIALA K., SIITONEN S., KEMPPAINEN E., PUOLAKKAINEN P., REPO H., Acute pancreatitis with organ dysfunction associates with abnormal blood lymphocyte signaling: controlled laboratory study, Crit. Care., 14, no. 6, 2010, p. 207.

13.STUMM M., REICHENSPURNER H., BARTEN M.J ., Successful therapy of pancreatitis after heart transplantation-A case series, J. Heart Lung Transplant, 35, no. 6, 2016, p. 835.

14.DANAHOLGLU A., MIRCHELL O.J., SINGH V.K., DANAHOGLU A.N., SENTURK H., CAMERON A.M, GURAKAR A., Acute pancreatitis following adult liver transplantation: A systematic review, Turk J. Gastroenterol., 26, no.6, 2015, p. 450.

15.Stumm M., Barten M.J., SILL B., BERNHARDT A., WAGNER F., REICHENSPURNER H., DEUSE T., Successful Treatment of Severe Pancreatitis Following Heart Transplantation: A Case Series, Thorac. Cardiovasc. Surger., 63, no. 1, 2015, p. 48.

16.0GUNSEINDE B.A.,WIMMERS E., WASHINGTON B., IYOB B., CROOPER T., CALLENDER C.O., A case of tacrolimus (FK 506) induced pancreatitis and fatality 2 years postcadaveric renal transplant, Transplantation, 76, no. 2, 2003, p. 448.

17.WARSHAW A.L., O' HARE P.J., Susceptibility of the pancreas to ischemic injury in shock, Ann. Surg., 188, no. 2, 1987, p.197.

18.WANG S., MA L., ZHUANG Y., JIANG B., ZHANG X., Screening and risk factors of exocrine pancreatic insufficiency in critically ill adult patients receiving enteral nutrition, Crit. Care., 17, no. 4, 2013; p. 17. 19.CIUNTU, B.M., VASILUTA, V., GEORGESCU, S.O., Negative Pressure Therapy in Abdominal Compartment Syndrome, Rev. Chim. (Bucharest), 68, no. 8, 2017, p. 1923.

$\overline{\text { Manuscript received: } 7.05 .2019}$ 